\title{
Antibody-based immunotherapeutic attempts in experimental animal models of prion
}

\section{diseases}

Suehiro Sakaguchi ${ }^{1)}$, Daisuke Ishibashi ${ }^{2)}$, and Haruo Matsuda ${ }^{3)}$

${ }^{1)}$ Division of Molecular Neurobiology, The Institute for Enzyme Research, The University of

Tokushima, 3-18-15 Kuramoto-cho, Tokushima 770-8503, Japan

${ }^{2)}$ Department of Molecular Microbiology and Immunology, Nagasaki University Graduate

School of Biomedical Sciences, Sakamoto 1-12-4, Nagasaki 852-8523, Japan

3) Laboratory of Immunology, Department of Molecular and Applied Bioscience, Graduate

School of Biosphere Science, Hiroshima University, 1-4-4 Kagamiyama, Higashi-Hiroshima, Hiroshima 739-8528, Japan

\section{Affiliation}

Suehiro Sakaguchi

Division of Molecular Neurobiology, The Institute for Enzyme Research, The University of

Tokushima, 3-18-15 Kuramoto-cho, Tokushima 770-8503, Japan

Tel: $+81-88-633-7438$

Fax: +81-88-633-7440

E-mail: sakaguch@ier.tokushima-u.ac.jp 
Daisuke Ishibashi

Department of Molecular Microbiology and Immunology, Nagasaki University Graduate School of Biomedical Sciences, Sakamoto 1-12-4, Nagasaki 852-8523, Japan

Tel: +81-95-819-7059

Fax: +81-95-819-7060

E-mail: dishibashi-ngs@umin.ac.jp

Haruo Matsuda

Laboratory of Immunology, Department of Molecular and Applied Bioscience, Graduate School of Biosphere Science, Hiroshima University, 1-4-4 Kagamiyama, Higashi-Hiroshima, Hiroshima 739-8528, Japan

Tel \& Fax: +81-82-424-7968

E-mail: hmatsu@hiroshima-u.ac.jp 


\section{Abstract}

Background: There has been a dramatic decrease in the risk of transmission of bovine spongiform encephalopathy to humans. In contrast, the risk of human-to-human transmission of variant Creutzfeldt-Jakob disease (vCJD) via medical treatments became potentially high since 4 vCJD cases were reported to be possibly transmitted via blood transfusion in the United Kingdom. However, no treatments are yet available for curing prion diseases. Objective: Conversion of the normal prion protein, $\operatorname{PrP}^{\mathrm{C}}$, to the amyloidogenic $\operatorname{Pr} \mathrm{P}, \operatorname{PrP}^{\mathrm{Sc}}$, plays a pivotal role in the pathogenesis. Recently, certain anti-PrP or anti-37/67-kDa laminin receptor (LRP/LR) antibodies were shown to have the potential to cure chronically infected cells, clearing $\operatorname{PrP}^{\mathrm{Sc}}$ from the cells. This has raised the possibility of antibody based-immunotherapy for prion diseases. This article aims to introduce and discuss the recently published attempts of immunotherapy in prion diseases. Methods: Bibliographic research was carried out using the PubMed database. Patent literature was searched using the UK Intellectual Property Office website. Results/Conclusion: No satisfying consequences in animals could be detected with anti-PrP antibodies directly infused into the brains of animals by the intraventricular route or by anti-PrP or anti-LRP/LR single chain fragment antibodies directly delivered into the brain by virus vector-mediated gene transfer. This is probably because such delivery systems failed to deliver the antibodies to the neurons relevant for the treatments.

Keywords: prion, prion protein, prion diseases, antibody, immunotherapy 


\section{Introduction}

Prion diseases or transmissible spongiform encephalopathies are a group of devastating neurodegenerative disorders that include Creutzfeldt-Jakob disease (CJD),

Gerstmann-Sträussler-Scheinker syndrome (GSS), fatal familial insomnia (FFI), and kuru in humans and scrapie and bovine spongiform encephalopathy (BSE) in animals [1, 2]. A sporadic type of CJD accounts for $85 \%-90 \%$ of most of prion diseases in human beings [2]. The etiology of sporadic CJD remains unknown [2]. Interestingly, approximately $10 \%$ of cases are inherited, including those of familial CJD, GSS, and FFI [2]. These inherited diseases are etiologically linked to specific mutations of Prnp, the gene for prion protein (PrP) [2]. Other types of the diseases are caused by infectious events, including iatrogenic CJD, kuru, and variant CJD (vCJD) [2]. Most cases of the infectious type are iatrogenic CJDs [3-6]. Kuru is a disease that emerged due to ritualistic cannibalism in Papua New Guinea [7]. vCJD is thought to be transmitted from BSE-infected cattle via contaminated food $[8,9]$. No effective therapy for these diseases has been developed yet.

The advent of vCJD has raised concerns of the possibility of a disease epidemic among the human population $[10,11]$. However, only $~ 160$ cases of vCJD have thus far been reported in England and a much lesser number of cases in other countries

(http://www.cjd.ed.ac.uk/figures.htm). This low number of vCJD cases could be attributed to the inefficiency of oral transmission, the species barrier between cattle and humans, and the marked reduction in BSE cases due to the ban on using meat and bone meal ingredients in animal feed. However, new cases of BSE are still reported in the United Kingdom (UK) and other countries 
(http://niah.naro.affrc.go.jp/disease/bse/count.html). Therefore, we still have to constantly survey the disease. Another animal prion disease, the chronic wasting disease, is spreading within mule deer and elk in North America [12], raising similar health concerns of the possibility of the disease being transmitted to humans, causing another type of vCJD.

Four cases of vCJD considered to be transmitted via blood transfusion have been reported in the UK [13-16], raising the more serious concern of human-to-human secondary transmission of vCJD via medical treatments or procedures. vCJD is more transmissible among human populations than is BSE from cattle to humans. In humans, codon 129 of Prnp is polymorphic, coding methionine $(\mathrm{M})$ or valine $(\mathrm{V})$, and is a major determinant of susceptibility to the disease: MM is the most susceptible; MV, intermediate; and VV, protective [17-19]. All cases of vCJD due to BSE, reported to date, have been found in MM individuals [20]. No MV or VV cases have been identified thus far [20]. However, one case of blood transfusion-related vCJD was heterozygous at codon 129 [14]. These results suggest that vCJD might be transmissible to humans with any genotypes of Prnp. Consistent with these results, it was shown that vCJD was transmitted to mice expressing human PrP with MM, MV, or VV [20]. Thus, it is believed that there might be a considerable number of individuals who are latently infected with vCJD without any clinical symptoms, and that these latently infected people might become the sources of secondary transmission of vCJD. Indeed, Hilton et al. reported a much greater incidence of the disease than that so far reported for conventional human prion diseases. They showed that 3 out of 12,674 surgically removed appendectomy or tonsillectomy specimens were positive for staining of $\operatorname{PrP}^{\mathrm{Sc}}$, although two specimens displayed a dissimilar staining pattern of $\operatorname{PrP}^{\mathrm{Sc}}$ from 
that in vCJD [21]. Therefore, the development of therapeutic and/or prophylactic measures for prion diseases is urgently awaited.

Recently, in addition to chemical compound-based conventional therapeutic approaches, a new approach of antibody-based immunotherapeutics is being attempted using experimental animal models of prion diseases. Here, we will introduce and discuss such immunotherapeutic attempts.

\section{Therapeutic targets for prion diseases}

The causative agents of prion diseases, the so-called prions, are thought to be composed of the abnormally folded, amyloidogenic isoform of $\operatorname{PrP}$, termed $\operatorname{PrP}^{\mathrm{Sc}}[22] . \operatorname{PrP}^{\mathrm{Sc}}$ is generated via the conformational conversion of the normal cellular isoform of $\operatorname{PrP}, \operatorname{PrP}^{\mathrm{C}}$, a membrane glycoprotein anchored to the cell surface via a glycosylphosphatidylinositol (GPI) moiety and expressed in various tissues, with the highest expression in the brain, particularly in neurons [22, 23]. Accumulating lines of evidence indicate that the conformational conversion of $\operatorname{PrP}^{\mathrm{C}}$ into $\operatorname{PrP}^{\mathrm{Sc}}$ plays a pivotal role in the pathogenesis of prion diseases. Indeed, along with other researchers' studies, we have shown that $\operatorname{PrP}^{\mathrm{C}}$-deficient $\left(\operatorname{Prnp}^{0 / 0}\right)$ mice, in which the conversion never occurs due to lack of $\operatorname{PrP}^{\mathrm{C}}$, were resistant to the diseases even after inoculation with mouse-adapted prions [24-27]. Moreover, it was reported that the removal of $\operatorname{PrP}^{\mathrm{C}}$ specifically from the infected neurons rescued mice from the disease $[28,29]$, indicating that neurons undertaking the conversion may undergo degeneration. Therefore, inhibition of the conversion in the brain, particularly in neurons, may be therapeutic for prion diseases. 
Yokoyama et al. carried out histoblot analysis of scrapie prion-infected mouse and hamster brains and showed that immunoreactive signals against $\operatorname{PrP}^{\mathrm{C}}$ were decreased in the affected regions whereas those against $\mathrm{PrP}^{\mathrm{Sc}}$ were increased [30]: this suggested that constitutive conversion might lead to a decrease in $\operatorname{PrP}^{\mathrm{C}}$ in the brains and that the resultant functional impairment of $\operatorname{PrP}^{\mathrm{C}}$ might be involved in the pathogenesis. Indeed, $\operatorname{Prnp}{ }^{0 / 0}$ mice spontaneously developed abnormal phenotypes, some of which are often observed in prion diseases, including behavioral alterations in circadian activity and sleep, and demyelinated axons in the spinal cord and peripheral nerves [31-34]. It is therefore possible that such abnormalities in prion diseases might be attributable to the functional loss of $\operatorname{PrP}^{\mathrm{C}}$. Thus, approaches to enhance the function of $\operatorname{PrP}^{\mathrm{C}}$ might be alternatively therapeutic against prion diseases. However, the physiological function of $\operatorname{PrP}^{\mathrm{C}}$ remains unknown. In contrast to the reduction in $\operatorname{PrP}^{\mathrm{C}}$, constitutive conversion causes the accumulation of $\operatorname{PrP}^{\mathrm{Sc}}$ in the brain. It is therefore suggested that $\operatorname{PrP}^{\mathrm{Sc}}$ might be a toxic neurodegenerative molecule. Indeed, the accumulation of $\operatorname{PrP}^{\mathrm{Sc}}$ is well correlated to pathological changes, including gliosis, spongiform changes, and neuronal cell death [2]. Moreover, an amyloidogenic $\mathrm{PrP}$ peptide, $\mathrm{PrP} 106-126$, or purified $\mathrm{PrP}^{\mathrm{Sc}}$ was shown to be toxic to cultured cells, inducing apoptotic cell death [35-37]. Therefore, approaches that lead to the protection of neurons from $\mathrm{PrP}^{\mathrm{Sc}}$ neurotoxicity might also be therapeutic.

\section{Anti-prion chemical compounds}

A large number of chemical compounds were screened for anti-prion activity or activity that reduces the total amount of $\mathrm{PrP}^{\mathrm{Sc}}$ in chronically infected cultured cells, such as scrapie 
prion-infected mouse neuroblastoma $\mathrm{N} 2$ a cells $[38,39]$. As a result, many compounds have been isolated as therapeutic candidates for prion diseases (Table 1). However, the chemical characteristics of these compounds are diverse and, for most of them, the exact mechanism of the anti-prion activity remains unknown.

The compounds that could reduce $\mathrm{PrP}^{\mathrm{Sc}}$ levels in infected cells were then tested for their therapeutic usefulness in prion-infected animals. These compounds showed prophylactic effects on the disease, prolonging incubation times or rescuing the animals from the disease when administered to animals before or immediately after prion inoculation [38, 39]. However, no curable effects of these compounds could be detected [38, 39]. Prolongation of incubation times became marginal and no animals were rescued from the disease when the compounds were administered at an advanced stage or in the clinical phase of the disease. This therapeutic ineffectiveness of the compounds is probably because the compounds fail to efficiently reach the therapeutically relevant brain regions due to their inability to cross the blood-brain barrier (BBB) or their inadequate spreading within the brain parenchyma even after direct administration into the brain. It is also conceivable that the compounds might be less effective against prions in the brain at an advanced clinical stage of the disease. Recently, De Luigi et al. reported that even a single intracerebroventricular infusion of liposome-entrapped doxycycline and minocycline, termed LipoDoxycycline and LipoMinocycline, respectively, into hamsters at an advanced stage of prion disease could significantly extend incubation times by 10 and 14 days, respectively [40]. It is thus interesting to investigate whether or not continuous or multiple infusions of the compounds could be more effective and cure animals of prion diseases. 
Only a few compounds have been clinically tested against prion diseases so far.

However, no patients have been reported to be cured from the diseases by treatment with these compounds, although some reports have shown that clinical symptoms, such as decreased cognitive activities, appeared to be slightly improved. Pentosan polysulfate (PPS) is a polyanionic compound exhibiting marked anti-prion activity in prion-infected cells by blocking the binding of the $37 / 67-\mathrm{kDa}$ laminin receptor (LRP/LR), a possible prion receptor, to $\operatorname{PrP}^{\mathrm{Sc}}$ on the cell surface [41], and was directly injected into the brain ventricle of patients with various types of prion diseases $[42,43]$. Bone et al. showed that the mean survival of all treated patients was longer than the reported values for non-treated patients [43]. However, due to lack of proper controls, the therapeutic benefits of PPS remain to be proven. Quinacrine, an anti-malarial agent, has anti-prion activity. A large-scale randomized controlled clinical trial of quinacrine is being undertaken in the UK as the PRION-1 study (http://www.ctu.mrc.ac.uk/studies/cjd.asp). Nakajima et al. reported transient and modest improvement in mood or cognitive function by treatment of 3 patients with quinacrine [44]. Flupirtine is a centrally acting, non-opiate analgesic compound as also an anti-apoptotic agent. A double-blind, placebo-controlled study in 28 CJD patients by Otto et al. showed that flupirtine improved patients' scores on several different dementia tests as compared to placebo [45]. These treatments were clinically unsuccessful probably because of the same reasons for which the compounds were ineffective in animal models. Thus, appropriate chemical modifications that enable the compounds to efficiently cross the BBB would be required for the compounds to be more effective. In addition, the compounds were administered to clinically advanced patients due to the lack of effective procedures that can diagnose presymptomatic 
individuals, which might have reduced the anti-prion activity of the compounds. Therefore, the development of more sensitive diagnostic techniques for the detection of preclinical patients is essential.

\section{Antibodies cure chronically infected cultured cells}

\subsection{Anti-PrP antibodies}

Peretz et al. first reported that recombinant PrP-specific Fab fragments cured chronically infected N2a cells [46]. They added PrP-specific Fab fragments, termed D13, D18, R1, R2, E123, E149, and R72, to chronically infected N2a cell cultures for 7 days. The anti-prion activity of the Fab fragments was then assessed by calculating the values of 50\%-inhibitory concentration $\left(\mathrm{IC}_{50}\right)$, the concentration necessary for halving $\mathrm{PrP}^{\mathrm{Sc}}$ levels. Fabs D13 and D18 were most effective with the $\mathrm{IC}_{50}$ being $0.6 \mu \mathrm{g} / \mathrm{ml}(12 \mathrm{nM})$ and $0.45 \mu \mathrm{g} / \mathrm{ml}(9 \mathrm{nM})$, respectively. Fabs R1 and R2 were slightly less efficient, with the $\mathrm{IC}_{50}$ being $2.5 \mu \mathrm{g} / \mathrm{ml}(50 \mathrm{nM})$ and $2.0 \mu \mathrm{g} / \mathrm{ml}(40 \mathrm{nM})$, respectively. Prion infectivity was concomitantly reduced in these cells by over three orders of magnitude. Fabs D12, D18, R1, and R2 recognize residues 95-103, 132-156, 220-231, and 225-231, respectively, indicating that anti-prion activity might be independently mediated via broadly located multiple sites of PrP. In contrast, no reduction in $\mathrm{PrP}^{\mathrm{Sc}}$ levels and prion infectivity were detected in the cells treated with Fabs E123, E149, and R72, which bind to residues 29-37, 72-86, and 151-162, respectively. Enari et al. reported similar results [47]: they added an anti-PrP monoclonal antibody (mAb), termed $6 \mathrm{H} 4$ which binds to residues $144-152$ to their newly established infected $\mathrm{N} 2 \mathrm{a} / \mathrm{Bos} 2$ cells and showed that the antibody reduced $\operatorname{PrP}^{\mathrm{Sc}}$ levels in the cells in a dose-dependent 
manner.

\subsection{Possible anti-prion mechanisms of anti-PrP antibodies}

The first step of the conversion is an interaction between $\operatorname{PrP}^{\mathrm{C}}$ and $\mathrm{PrP}^{\mathrm{Sc}}$ probably on the cell surface, particularly on lipid rafts, and/or along the endocytotic pathway to late endosomes/lysosomes [48]. It is therefore envisaged that anti-prion antibodies might interfere with the interaction. It has been reported that 3F4 and 13A5 mAbs, which recognize residues 109-112 and 138-165, respectively, and the polyclonal antibody against residues 219-232 disturbed the interaction and subsequently inhibited the conversion in a cell-free system $[49,50]$. Another possibility is that anti-PrP antibodies might reduce $\mathrm{PrP}^{\mathrm{Sc}}$ levels in infected cells by altering the subcellular localization of $\operatorname{PrP}^{\mathrm{C}}$. Kim et al. showed that 31C6, 110, 44B1, and 72 anti-PrP mAbs with anti-prion activity disturbed $\operatorname{PrP}^{\mathrm{C}}$ internalization [51]. The $31 \mathrm{C} 6$ and 110 mAbs react with residues 143-149 and the PHGGGWG sequence at residues 59-65 and 83-89 in the octapeptide repeat region, respectively, and 44B1 and $72 \mathrm{mAbs}$ recognize discontinuous epitopes [51]. Perrier et al. showed that the anti-PrP mAbs SAF34 and SAF61, which react with the octapeptide repeat region and residues 144-152, respectively, accelerated the degradation of $\operatorname{PrP}^{\mathrm{C}}$ in cells [52], suggesting another possibility that anti-PrP antibodies might inhibit $\operatorname{PrP}^{\mathrm{Sc}}$ formation by reducing $\operatorname{PrP}^{\mathrm{C}}$. It is further possible that anti-PrP antibodies might interfere with the interaction of the so-called cofactor(s), which is postulated to play an important role in the conversion, with either $\operatorname{PrP}^{\mathrm{C}}$ or $\mathrm{PrP}^{\mathrm{Sc}}$, or both. 


\subsection{Anti-LRP/LR antibody}

It was shown that LRP/LR interacts with $\operatorname{PrP}^{\mathrm{C}}$ directly between LRP/LR residues 161-179 and PrP residues 144-179, and indirectly between LRP/LR residues 101-160 or 180-285 and PrP residues 53-93 via a heparan sulfate chain of proteoglycan $[53,54]$. Subsequently, LRP/LR was also demonstrated to act as the cell-surface receptor for $\operatorname{PrP}^{\mathrm{C}}[55]$ and $\operatorname{PrP} 27-30$, the proteinase K-resistant core of $\operatorname{PrP}^{\mathrm{Sc}}$ [41]. These indicate that LRP/LR might be involved in $\operatorname{PrP}^{\mathrm{Sc}}$ formation. Indeed, Leucht et al. reported that the LRP/LR-specific polyclonal antibody, termed W3, competed with recombinant PrP for binding to the LRP/LR expressed on the cell surface, reduced $\mathrm{PrP}^{\mathrm{Sc}}$ levels in infected N2a cells, and finally cured the cells [56]. This result indicates that W3 might inhibit $\mathrm{PrP}^{\mathrm{Sc}}$ formation by disturbing the interaction between $\mathrm{PrP}^{\mathrm{C}}$ and LRP/LR. W3 was also shown to reduce $\operatorname{PrP}^{\mathrm{C}}$ levels in cells [56]. It is thus alternatively possible that the W3-mediated dissociation between LRP/LR and $\operatorname{PrP}^{\mathrm{C}}$ might destabilize $\operatorname{PrP}^{\mathrm{C}}$, or that LRP/LR-PrP ${ }^{\mathrm{C}}-\mathrm{W} 3$ complexes might stimulate the internalization of $\operatorname{PrP}^{\mathrm{C}}$ into lysosomes for degradation, resulting in inhibition of $\operatorname{PrP}^{\mathrm{Sc}}$ formation. Thus, LRP/LR might be a therapeutic target of prion diseases [57-60].

\section{Immunotherapeutic attempts in experimental animal models of prion diseases}

\subsection{Direct infusion of anti-PrP antibodies into the brain}

In a previous study, we produced anti-PrP $\mathrm{mAbs}$, termed $3 \mathrm{~S} 9$ and $2 \mathrm{H} 9$ that recognize residues 141-161 and 151-221, respectively, and showed that both mAbs have anti-prion activity, reducing $\mathrm{PrP}^{\mathrm{Sc}}$ levels in infected $\mathrm{N} 2 \mathrm{a}$ cells [61]. The $\mathrm{IC}_{50}$ value of $3 \mathrm{~S} 9 \mathrm{mAb}$ was $0.6 \mathrm{nM}$, which was over 
10 times stronger than that $(8.4 \mathrm{nM})$ of $2 \mathrm{H} 9 \mathrm{mAb}$. Hence, we were interested in studying the immunotherapeutic potential of $3 \mathrm{~S} 9 \mathrm{mAb}$ against prion diseases. Antibodies are macromolecules and are, therefore, unable to pass the BBB. White et al. demonstrated that prophylactic intraperitoneal administration of two anti-PrP mAbs, ICSM 18 and 35 [62], could protect mice from the peripheral infection of RML prions but had no effects on prions directly introduced into the brains of mice [63]. This could be due to the incapability of the antibodies to cross the BBB. Therefore, we directly administered $3 \mathrm{~S} 9 \mathrm{mAb}$ into the right ventricle of mice that had been intracerebrally inoculated with a mouse-adapted Fukuoka-1 prion (SS and DI, unpublished data). The antibody was continuously delivered into the ventricle using the ALLZET mini-osmotic pump model 2004 (DURECT Corporation) at a flow rate of $0.25 \pm 0.05 \mu \mathrm{g} / \mathrm{h}$ for 28 days from 8 or 13 weeks post inoculation (p.i.), which corresponds to the middle or late disease stage, respectively. Mice infused with control $\operatorname{IgG}$ antibody at 8 or 13 weeks p.i. developed the disease at $117.8 \pm 9.9$ and $121.2 \pm 2.5$ days p.i. and eventually died at $122.5 \pm 6.1$ and $124.0 \pm 3.7$ days p.i., respectively (Table 2). Unexpectedly, no significant extension in incubation times and survival times could be detected in mice treated with $3 \mathrm{~S} 9 \mathrm{mAb}$. The mice treated at 8 or 13 weeks p.i. succumbed to the disease at $127.0 \pm 9.0(P=0.158$, Logrank test $)$ and $125.0 \pm 4.7$ days p.i. $(P$ $=0.851)$ and died at $130.0 \pm 11.7(P=0.272)$ and $127.2 \pm 5.8$ days p.i. $(P=0.942)$, respectively (Table 2). In contrast, $\operatorname{PrP}^{\mathrm{Sc}}$ levels were reduced in the brains of mice treated with $3 \mathrm{~S} 9 \mathrm{mAb}$ at 8 weeks p.i. to half of those in the control mice. However, no decrease in $\operatorname{PrP}^{\mathrm{Sc}}$ levels could be observed in mice treated at 13 weeks p.i.

On the other hand, Song et al. reported that $31 \mathrm{C} 6 \mathrm{mAb}$ carrying anti-prion activity $(0.7$ 
$\mathrm{nM} \mathrm{IC}_{50}$ ) could marginally but significantly prolong survival times in mice that had been intracerebrally inoculated with Chandler prion [64]. The dose of the mAb used was twice $(0.5$ $\mu \mathrm{g} / \mathrm{h})$ that of $3 \mathrm{~S} 9 \mathrm{mAb}(0.25 \mu \mathrm{g} / \mathrm{h})$ used by us. The mAb was infused for 28 days into the left ventricle of the mice at 60 (corresponding to the early stage), 90 (the middle stage), or 120 days p.i. (the late stage). The treated mice survived the disease by approximately 10 days more than did the control mice, regardless of the time points of treatment. Moreover, milder pathologies including $\mathrm{PrP}^{\mathrm{Sc}}$ accumulation, gliosis, and vaccuolation were consistently observed in the brains of the treated mice. Interestingly, 31C6 mAb was less effective against a different Obihiro prion. Mice inoculated with an Obihiro prion could survive the disease by approximately 10 days more than the control mice, only when the treatment was started at 60 days p.i., but not at 90 and 120 days p.i. These results suggest that the anti-prion effect of anti-PrP antibodies may differ for each of the prion strains.

\subsection{Virus vector-mediated gene delivery of anti-PrP scFv antibodies}

The direct intraventricular infusion of anti-prion antibodies presented only slight therapeutic benefits against prion disease in mice. Due to their higher molecular weight, the intraventricularly injected antibodies are unable to infiltrate regions where neurons mediating vital functions are infected by prions at concentrations that are sufficiently high for the antibodies to exert therapeutic effects. Indeed, Lefebvre-Roque et al. observed that, compared to whole IgGs, lower molecular weight $\mathrm{F}\left(\mathrm{ab}^{\prime}\right)_{2}$ fragments were more widely distributed at higher concentrations in the brain of mice when intraventricularly injected [65]. Therefore, a reduction in the molecular size of 
anti-PrP antibodies without reducing their anti-prion activity might be helpful in overcoming this problem [66]. It has already been shown that fragmented anti-PrP antibodies, such as Fab and $\mathrm{scFv}$ antibodies, remain active against $\operatorname{PrP}^{\mathrm{Sc}}$ formation in infected cells $[67,68]$. However, Fab and scFv antibodies have the disadvantage of a short half-life, compared to full-length antibodies. Therefore, such fragmented anti-PrP antibodies require to be modified to overcome this problem. In addition, the development of systems for the efficient delivery of the fragmented antibodies into the brain, particularly to neurons relevant for therapy, would be very important to increase the therapeutic benefits of the antibodies in prion diseases.

Recently, the anti-PrP potential of anti-PrP scFv fragments was investigated in mice using a virus vector-mediated brain delivery system [69]. Several serotypes of recombinant adeno-associated vector (rAAV) are useful as gene delivery vehicles to treat neurological disorders due to their efficient gene transduction into neurons and their safety profiles [70-72]. However, there exist several potential limitations for using the vectors. The first is the efficiency of gene delivery to target cells. Serotype 2 of rAAV (rAAV2) is the most commonly studied vector. rAAV2 preferentially transduces neurons in various regions of the brain, including the hippocampus, substantia nigra, and cerebellum, and in spinal cord. The transduction efficiency varies from one region to another. rAAV1 and rAAV5 have higher transduced distribution and number of neurons than does rAAV2. rAAV1 transduces neurons, and glial and ependymal cells: and rAAV5, neurons and astrocytes. In contrast, rAAV4 almost exclusively transduces ependymal cells. Prions affect neurons throughout the brain. Therefore, rAAV1 and rAAV5 may be more effective as therapeutic gene delivery vectors in prion diseases than would be rAAV2. However, it 
may be difficult for even rAAV1 and rAAV5 vectors to extend to regions remote from the injected site. Therefore, multiple injections or further development of the vectors to transduce all of the target cells would be required. The second limitation is the presence of preexisting or newly induced anti-AAV neutralizing antibodies. No report has shown that the preexisting antibodies influence the transduction efficiency of rAAV. In contrast, the repeated administration of rAAV into the airway surface has been shown to produce an increased titer of the antibodies and reduced the transduction efficiency $[73,74]$. However, it was reported that repeated injection of rAAV vectors into the rat or mouse brain was possible $[75,76]$. The third limitation is the duration of the expression of a delivered gene. The stable expression of an rAAV2-delivered gene was observed at least up to 9 months in the rat brain [71].

Wuertzer et al. generated an rAAV2 vector encoding anti-PrP scFv fragments, termed scFv 3:3, scFv 6:4, scFv 6:6, and scFv D18 [69]. Each rAAV2 scFv vector with $9 \times 10^{9}$ expression units was bilaterally injected into the thalamus and striatum of mice: and 1 month later, the mice were intraperitoneally inoculated with RML prions [69]. Mice treated with the control vector developed the disease at $199 \pm 1$ days p.i. No significant prolongation in incubation times could be detected in mice injected with rAAV scFv 6:4 and 6:6. However, mice injected with rAAV scFvs 3:3 and D18 showed significantly extended incubation times of $222 \pm 13$ and $250 \pm$ 8 days p.i., respectively. Reduced accumulation of $\operatorname{PrP}^{\mathrm{Sc}}$ was also observed in the brains of mice injected with rAAV scFvs D18. These different anti-prion activities of the rAAV scFvs were well correlated to their binding affinity to recombinant PrP. These results indicate that anti-PrP scFv fragments transduced by the rAAV2 vector-mediated gene transfer were effective in inhibiting 
$\mathrm{PrP}^{\mathrm{Sc}}$ formation in the brains. However, regions expressing scFvs appeared restricted to sites where the rAAV2 scFvs were injected. Thus, the incomplete prophylactic prevention of the disease by rAAV2 vector-mediated gene transfer of the anti-PrP scFv fragments might be attributable to this limited regional expression of the scFvs in the brain. Campana et al. produced another lentivirus vector for scFv D18 and tested it for its anti-prion activity in prion-infected N2a cells [68]. Results showed that the lentivirus could transduce scFv D18 in the cells more efficiently than could rAAV2 [68]. However, as in the case of the rAAV2-mediated gene transfer, the transduction efficiency of anti-PrP scFv fragments in the brain might be low even with lentivirus-mediated gene transfer.

\subsection{Toxic anti-PrP antibodies}

In contrast to the beneficial effects of anti-PrP antibodies, neurotoxic effects were reported with some anti-prion mAbs or Fab fragments. Solforosi et al. showed that anti-PrP D13 and P mAbs each recognizing epitopes within the residues 95-105 of PrP were toxic, causing neuronal cell death in normal mice when directly injected into the hippocampus or the cerebellar cortex [77]. In contrast, another anti-PrP D18 mAb against the residues 133-157 did not manifest any neurotoxicity [77]. Lefebvre-Roque et al. also reported that anti-prion $4 \mathrm{H} 11 \mathrm{mAb}$ or its $\mathrm{F}(\mathrm{ab})_{2}$ fragment induced extensive neuronal cell death and marked gliosis over the brain when administered daily for 2 weeks into the lateral ventricle of $\operatorname{Tg} 20$ mice that had been infected with the 6PB1 mouse-adapted BSE prion by the intraperitoneal route [65]. The treatment was initiated in the early stage of neuroinvasion (85 days p.i.) [65]. The neuronal loss was observed in regions 
close to the injected lateral ventricle as well as in the occipital cortex, the hippocampus, the thalamus, and the striatum. No significant difference in the survival times could be detected between treated and untreated groups. Mice treated with $4 \mathrm{H} 11 \mathrm{mAb}$ or its $\mathrm{F}\left(\mathrm{ab}{ }^{\prime}\right)_{2}$ fragment died at $140 \pm 8$ and $143 \pm 14$ days p.i. against $143 \pm 10$ and $144 \pm 11$ days p.i. for the control $\operatorname{IgG}$ and $\mathrm{F}(\mathrm{ab})_{2}$ fragment, respectively. However, we detected no neuronal loss in the brains of mice inoculated with 3S9 mAb (SS and DI, unpublished data). No neurotoxicity was also reported in mice injected with 31C6 mAbs [64]. The neurotoxic 4H11, D13, and P mAbs bind to epitopes located within the N-terminal part of PrP. $4 \mathrm{H} 11$ mAb binds to the OR region (residues 51-90), and D13 and P mAbs recognize epitopes within residues 95-105. In contrast, nontoxic 3S9 and 31C6 mAbs bind to epitopes within residues 141-161 of the C-terminal part of PrP. Thus, the binding of anti-PrP antibodies to certain regions within the N-terminal part, such as the OR region or residues 95-105, might elicit a neurotoxic signal by either activating or adversely preventing the physiological function of $\operatorname{PrP}^{\mathrm{C}}$ in neurons.

\subsection{Anti-LRP/LR antibody}

To investigate the prophylactic anti-prion activity of the polyclonal anti-LRP/LR antibody W3 in vivo, $\mathrm{W} 3$ was peripherally injected into mice via the intraperitoneal route once a week over a period of 12 weeks [78]. The mice were intraperitoneally inoculated with RML prions 1 week after the first W3 injection. No significant prolongation in incubation times or survival was detected in the treated mice, probably due to the inability of the antibody to cross the BBB. However, $\mathrm{PrP}^{\mathrm{Sc}}$ levels were reduced by $17 \%$ in the brains and by $66 \%$ in the spleens of the mice, 
compared to those in control mice, indicating that W3 could interfere with peripheral but not the neuronal formation of $\mathrm{PrP}^{\mathrm{Sc}}$ [78]. Similar results were reported with anti-LRP/LR scFv fragments, termed $\mathrm{S} 18[79,80]$. S18 scFv reduced $\mathrm{PrP}^{\mathrm{Sc}}$ by approximately $40 \%$ in the spleens of mice infected with RML prions when intraperitoneally injected once a week for 8 weeks from 1 day prior to the infection. These results clearly indicate that anti-LRP/LR antibody or scFv is active in vivo and is able to reduce $\mathrm{PrP}^{\mathrm{Sc}}$ levels.

Zuber et al. used rAAV2 as a vector for anti-LRP/LR scFvs to be transduced into the brain [81]. They generated rAAV2 encoding two different scFvs, S18 and N3, and injected $5 \times$ $10^{9}$ particles of each $\mathrm{rAAV} 2 \mathrm{scFv}$ into the hippocampus of mice that were inoculated with RML prions in the same area 2 weeks after rAAV2 scFv injection [81]. Thereafter, anti-LRP/LR scFvs were produced in the mouse brains. However, in contrast to the results of Wuertzer et al. [69], which showed that rAAV2 encoding anti-PrP scFvs 3:3 or D18 fragment was partially prophylactic, no prolongation in incubation times or survival was observed in mice that received rAAV2 scFv-S9 or N3. The authors suggested that the rAAVs might not have reached all the relevant brain cells that were infected by prions. Alternatively, anti-LRP/LR scFvs might be less effective in preventing $\mathrm{PrP}^{\mathrm{Sc}}$ formation than are anti-PrP scFvs. Interestingly, the injected rAAV2s appeared to cross the BBB and also reach the spleen, where scFvs S18 and N3 were expressed and $\mathrm{PrP}^{\mathrm{Sc}}$ levels were reduced by approximately $32 \%$ and $60 \%$, respectively [81].

\subsection{PrP-Fc}

Meier et al. reported that wild-type mice transgenically expressing $\mathrm{PrP}-\mathrm{Fc}_{2}$, a dimeric fusion 
protein of $\operatorname{PrP}^{\mathrm{C}}$ linked to the $\mathrm{N}$-terminus of $\mathrm{IgG} \mathrm{Fc}$, showed marked resistant to RML prions, developing the disease with significantly prolonged incubation times and accumulating much less $\mathrm{PrP}^{\mathrm{Sc}}$ in the brains as compared to control non-transgenic mice [82]. $\mathrm{PrP}-\mathrm{Fc}_{2}$ had a potential to bind to $\operatorname{PrP}^{\mathrm{Sc}}$ via $\operatorname{PrP}^{\mathrm{C}}$, but the $\operatorname{PrP}^{\mathrm{C}}$ part could not be converted to $\operatorname{PrP}^{\mathrm{Sc}}$ probably due to fusion with Fc. The authors therefore suggested that $\mathrm{PrP}_{-} \mathrm{Fc}_{2}$ might inhibit $\mathrm{PrP}^{\mathrm{Sc}}$ formation by a dominant negative mechanism, in which $\operatorname{PrP}-\mathrm{Fc}_{2}$ disturbs the binding of native $\operatorname{PrP}^{\mathrm{C}}$ to $\operatorname{PrP} \mathrm{P}^{\mathrm{Sc}}$ by intercalation between the two molecules, resulting in the prevention of $\mathrm{PrP}^{\mathrm{Sc}}$ formation [82]. The same group further investigated the prophylactic activity of lentivirus vector-transduced $\mathrm{PrP}-\mathrm{Fc}_{2}$ against RML prions [83]. The $\mathrm{PrP}-\mathrm{Fc}_{2}$ lentivirus was injected into the hippocampus. When the mice were intracerebrally inoculated with RML prions 20 days after the virus injection with $3 \times$ $10^{8}$ infectious units, the mice developed the disease with prolonged incubation times by 36 days as compared to the control mice, which developed the disease at $175 \pm 5$ days p.i. Importantly, this prophylactic effect of lentivirus vector-transduced $\mathrm{PrP}-\mathrm{Fc}_{2}$ further increased when the virus vector was transduced into the brain with higher infectious units [83]. When mice were treated with $1.5 \times 10^{9}$ infectious units of the virus vector, the incubation times were further prolonged by 72 days (treated vs. control mice, $247 \pm 8$ vs. $175 \pm 5$ days p.i.). However, when the virus $(1.5 \times$ $10^{9}$ infectious units) was injected 30 days after prion inoculation, the post-exposure prophylactic effect of $\mathrm{PrP}-\mathrm{Fc}_{2}$ was reduced in the mice, but the incubation times remained significantly extended by 25 days. No curative effect of the lentivirus vector-transduced $\mathrm{PrP}-\mathrm{Fc}_{2}$ was observed in mice when the vector was injected at 121 days p.i. (the late stage of disease) [83]. The treated and control mice succumbed to the disease at $197 \pm 9$ and $197 \pm 17$ days p.i., respectively. 


\subsection{Potential unfavorable responses in the immunotherapy}

Because $\operatorname{PrP}^{\mathrm{C}}$ is a host-encoded glycoprotein expressed in various normal tissues, no immune responses are evoked against $\operatorname{PrP}^{\mathrm{C}}$ under physiological conditions as well as $\mathrm{PrP}^{\mathrm{Sc}}$ in prion diseases. LRP/LR is also a host-encoded protein. Therefore, exogenously injected antibodies against PrP and LRP/LR might cause autoimmune reactions in vivo although no abnormal symptoms have been reported in mice peripherally administered with anti-PrP or anti-LRP/LR W3 antibodies [63, 78]. Moreover, the injected antibodies might generate detrimental signals upon binding to $\operatorname{PrP}^{\mathrm{C}}$ or LRP/LR. Indeed, as described above, certain anti-PrP mAbs elicited neurotoxic signals by cross-linking of $\operatorname{PrP}^{\mathrm{C}}$ when injected into the brain $[65,77]$. Thus, the possibility that these unfavorable effects might be induced by antibody-based immunotherapy for prion diseases should be carefully considered.

\section{Expert opinion}

No complete cure of prion diseases in animals has been obtained with anti-PrP antibodies directly infused into the brain by the intraventricular route or by anti-PrP and anti-LRP/LR scFvs and $\operatorname{PrP}-\mathrm{Fc}_{2}$ directly delivered into the brain by virus vector-mediated gene transfer. This is probably because the antibodies could not infiltrate into the brain due to their higher molecular weight and because the virus vectors infected only those neurons that were located at or surrounding sites where the vectors were injected, resulting in the inability of the antibodies to reach and cure the infected neurons that would be essential and are relevant for effective treatments. Therefore, 
delivery systems that are more efficient need to be developed for administering anti-PrP or anti-LRP/LR antibodies, $\mathrm{scFv}$ fragments, and $\mathrm{PrP}-\mathrm{Fc}_{2}$ into the brain for greater therapeutic efficacy against prion diseases. In addition, the development of more sensitive preclinical diagnostic techniques is essential.

\section{Declaration of interest}

This study was partly supported by the Ministry of Health, Labour and Welfare, Japan.

\section{Bibliography}

Papers of special note have been highlighted as either of interest $(\bullet)$ or of considerable interest

$(\bullet \bullet)$ to readers.

1. $\quad$ Prusiner SB. Prions. Proc Natl Acad Sci U S A 1998;95(23):13363-13383.

2. DeArmond SJ, Prusiner SB. Etiology and pathogenesis of prion diseases. Am J Pathol 1995;146(4):785-811.

3. Duffy P, Wolf J, Collins G et al. Letter: Possible person-to-person transmission of Creutzfeldt-Jakob disease. N Engl J Med 1974;290(12):692-693.

4. Bernoulli C, Siegfried J, Baumgartner G et al. Danger of accidental person-to-person transmission of Creutzfeldt-Jakob disease by surgery. Lancet 1977;1(8009):478-479.

5. Koch TK, Berg BO, De Armond SJ, Gravina RF. Creutzfeldt-Jakob disease in a young adult with idiopathic hypopituitarism. Possible relation to the administration of cadaveric human growth hormone. N Engl J Med 1985;313(12):731-733.

6. Thadani V, Penar PL, Partington J et al. Creutzfeldt-Jakob disease probably acquired from a cadaveric dura mater graft. Case report. J Neurosurg 1988;69(5):766-769.

7. Gajdusek DC. Unconventional viruses and the origin and disappearance of kuru. Science 1977;197(4307):943-960.

8. Bruce ME, Will RG, Ironside JW et al. Transmissions to mice indicate that 'new variant' CJD is caused by the BSE agent. Nature 1997;389(6650):498-501.

- Describes probable transmission of BSE to humans.

9. Hill AF, Desbruslais M, Joiner S et al. The same prion strain causes vCJD and BSE. Nature 1997;389(6650):448-450, 526.

- Describes probable transmission of BSE to humans. 
10. Collee JG, Bradley R, Liberski PP. Variant CJD (vCJD) and bovine spongiform encephalopathy (BSE): 10 and 20 years on: part 2. Folia Neuropathol 2006;44(2):102-110.

11. Prusiner SB. Prion diseases and the BSE crisis. Science 1997;278(5336):245-251.

12. Williams ES. Chronic wasting disease. Vet Pathol 2005;42(5):530-549.

13. Llewelyn CA, Hewitt PE, Knight RS et al. Possible transmission of variant Creutzfeldt-Jakob disease by blood transfusion. Lancet 2004;363(9407):417-421.

\section{-• Describes the first case of possible human-to-human transmission of vCJD via blood transfusion.}

14. Peden AH, Head MW, Ritchie DL, Bell JE, Ironside JW. Preclinical vCJD after blood transfusion in a PRNP codon 129 heterozygous patient. Lancet 2004;364(9433):527-529.

$\bullet \quad$ Describes possible transmission of vCJD to human carrying a M/V 129 codon via blood transfusion.

15. Wroe SJ, Pal S, Siddique D et al. Clinical presentation and pre-mortem diagnosis of variant Creutzfeldt-Jakob disease associated with blood transfusion: a case report. Lancet 2006;368(9552):2061-2067.

16. Zou S, Fang CT, Schonberger LB. Transfusion transmission of human prion diseases. Transfus Med Rev 2008;22(1):58-69.

17. Brandel JP, Preece M, Brown P et al. Distribution of codon 129 genotype in human growth hormone-treated CJD patients in France and the UK. Lancet 2003;362(9378):128-130.

18. Cervenakova L, Goldfarb LG, Garruto R et al. Phenotype-genotype studies in kuru: implications for new variant Creutzfeldt-Jakob disease. Proc Natl Acad Sci U S A 1998;95(22):13239-13241.

19. Wadsworth JD, Asante EA, Desbruslais M et al. Human prion protein with valine 129 prevents expression of variant CJD phenotype. Science 2004;306(5702):1793-1796.

20. Bishop MT, Hart P, Aitchison L et al. Predicting susceptibility and incubation time of human-to-human transmission of vCJD. Lancet Neurol 2006;5(5):393-398.

21. Hilton DA, Ghani AC, Conyers L et al. Prevalence of lymphoreticular prion protein accumulation in UK tissue samples. J Pathol 2004;203(3):733-739.

-• $\quad$ Describes a possibility of a large number of people subclinically infected by vCJD.

22. Prusiner SB. Molecular biology of prion diseases. Science 1991;252(5012):1515-1522.

23. Oesch B, Westaway D, Walchli M et al. A cellular gene encodes scrapie PrP 27-30 protein. Cell 1985;40(4):735-746.

24. Bueler H, Aguzzi A, Sailer A et al. Mice devoid of PrP are resistant to scrapie. Cell 1993;73(7):1339-1347.

25. Prusiner SB, Groth D, Serban A et al. Ablation of the prion protein $(\mathrm{PrP})$ gene in mice prevents scrapie and facilitates production of anti-PrP antibodies. Proc Natl Acad Sci U S A 1993;90(22):10608-10612.

26. Sakaguchi S, Katamine S, Shigematsu K et al. Accumulation of proteinase K-resistant prion protein $(\mathrm{PrP})$ is restricted by the expression level of normal $\mathrm{PrP}$ in mice 
inoculated with a mouse-adapted strain of the Creutzfeldt-Jakob disease agent. J Virol 1995;69(12):7586-7592.

27. Manson JC, Clarke AR, McBride PA, McConnell I, Hope J. PrP gene dosage determines the timing but not the final intensity or distribution of lesions in scrapie pathology. Neurodegeneration 1994;3(4):331-340.

28. Mallucci G, Dickinson A, Linehan J et al. Depleting neuronal PrP in prion infection prevents disease and reverses spongiosis. Science 2003;302(5646):871-874.

29. Mallucci GR, White MD, Farmer M et al. Targeting cellular prion protein reverses early cognitive deficits and neurophysiological dysfunction in prion-infected mice. Neuron 2007;53(3):325-335.

30. Yokoyama T, Kimura KM, Ushiki Y et al. In vivo conversion of cellular prion protein to pathogenic isoforms, as monitored by conformation-specific antibodies. J Biol Chem 2001;276(14):11265-11271.

31. Tobler I, Gaus SE, Deboer T et al. Altered circadian activity rhythms and sleep in mice devoid of prion protein. Nature 1996;380(6575):639-642.

32. Nishida N, Tremblay P, Sugimoto $\mathrm{T}$ et al. A mouse prion protein transgene rescues mice deficient for the prion protein gene from purkinje cell degeneration and demyelination. Lab Invest 1999;79(6):689-697.

33. Gambetti P, Parchi P, Petersen RB, Chen SG, Lugaresi E. Fatal familial insomnia and familial Creutzfeldt-Jakob disease: clinical, pathological and molecular features. Brain Pathol 1995;5(1):43-51.

34. Neufeld MY, Josiphov J, Korczyn AD. Demyelinating peripheral neuropathy in Creutzfeldt-Jakob disease. Muscle Nerve 1992;15(11):1234-1239.

35. Forloni G, Angeretti N, Chiesa R et al. Neurotoxicity of a prion protein fragment. Nature 1993;362(6420):543-546.

36. Muller WE, Ushijima H, Schroder HC et al. Cytoprotective effect of NMDA receptor antagonists on prion protein (PrionSc)-induced toxicity in rat cortical cell cultures. Eur J Pharmacol 1993;246(3):261-267.

37. Hetz C, Russelakis-Carneiro M, Maundrell K, Castilla J, Soto C. Caspase-12 and endoplasmic reticulum stress mediate neurotoxicity of pathological prion protein. Embo J 2003;22(20):5435-5445.

38. Trevitt CR, Collinge J. A systematic review of prion therapeutics in experimental models. Brain 2006;129(Pt 9):2241-2265.

-• Systematically reviews anti-prion molecules.

39. Sakaguchi S. Recent developments in therapeutics for prion diseases. Expert Opin Ther Patents 2008;18(1):35-59.

- $\quad$ Systematically reviews anti-prion molecules.

40. De Luigi A, Colombo L, Diomede L et al. The efficacy of tetracyclines in peripheral and intracerebral prion infection. PLoS ONE 2008;3(3):e1888.

41. Gauczynski S, Nikles D, El-Gogo S et al. The 37-kDa/67-kDa laminin receptor acts as a receptor for infectious prions and is inhibited by polysulfated glycanes. J Infect Dis 2006;194(5):702-709. 
42. Rainov NG, Tsuboi Y, Krolak-Salmon P, Vighetto A, Doh-Ura K. Experimental treatments for human transmissible spongiform encephalopathies: is there a role for pentosan polysulfate? Expert Opin Biol Ther 2007;7(5):713-726.

43. Bone I, Belton L, Walker AS, Darbyshire J. Intraventricular pentosan polysulphate in human prion diseases: an observational study in the UK. Eur J Neurol 2008;15(5):458-464.

44. Nakajima M, Yamada T, Kusuhara T et al. Results of quinacrine administration to patients with Creutzfeldt-Jakob disease. Dement Geriatr Cogn Disord 2004;17(3):158-163.

45. Otto M, Cepek L, Ratzka P et al. Efficacy of flupirtine on cognitive function in patients with CJD: A double-blind study. Neurology 2004;62(5):714-718.

46. Peretz D, Williamson RA, Kaneko K et al. Antibodies inhibit prion propagation and clear cell cultures of prion infectivity. Nature 2001;412(6848):739-743.

\section{$\bullet \quad$ The first paper describing a possibility of antibody-based immunotherapy against} prion diseases.

47. Enari M, Flechsig E, Weissmann C. Scrapie prion protein accumulation by scrapie-infected neuroblastoma cells abrogated by exposure to a prion protein antibody. Proc Natl Acad Sci U S A 2001;98(16):9295-9299.

48. Harris DA. Cellular biology of prion diseases. Clin Microbiol Rev 1999;12(3):429-444.

49. Kaneko K, Peretz D, Pan KM et al. Prion protein (PrP) synthetic peptides induce cellular PrP to acquire properties of the scrapie isoform. Proc Natl Acad Sci U S A 1995;92(24):11160-11164.

50. Horiuchi M, Caughey B. Specific binding of normal prion protein to the scrapie form via a localized domain initiates its conversion to the protease-resistant state. Embo $\mathrm{J}$ 1999;18(12):3193-3203.

51. Kim CL, Karino A, Ishiguro N et al. Cell-surface retention of PrPC by anti-PrP antibody prevents protease-resistant PrP formation. J Gen Virol 2004;85(Pt 11):3473-3482.

52. Perrier V, Solassol J, Crozet C et al. Anti-PrP antibodies block PrPSc replication in prion-infected cell cultures by accelerating PrPC degradation. J Neurochem 2004;89(2):454-463.

53. Rieger R, Edenhofer F, Lasmezas CI, Weiss S. The human 37-kDa laminin receptor precursor interacts with the prion protein in eukaryotic cells. Nat Med 1997;3(12):1383-1388.

•• $\quad$ The first paper describing interaction between LRP/LR and PrP ${ }^{\mathrm{C}}$.

54. Hundt C, Peyrin JM, Haik S et al. Identification of interaction domains of the prion protein with its 37-kDa/67-kDa laminin receptor. Embo J 2001;20(21):5876-5886.

55. Gauczynski S, Peyrin JM, Haik S et al. The 37-kDa/67-kDa laminin receptor acts as the cell-surface receptor for the cellular prion protein. Embo J 2001;20(21):5863-5875.

- $\quad$ Demonstrates LRP/LR as the receptor for $\operatorname{PrP}^{\mathrm{C}}$.

56. Leucht C, Simoneau S, Rey C et al. The $37 \mathrm{kDa} / 67 \mathrm{kDa}$ laminin receptor is required for $\operatorname{PrP}(\mathrm{Sc})$ propagation in scrapie-infected neuronal cells. EMBO Rep 2003;4(3):290-295.

57. Ludewigs $\mathrm{H}, \mathrm{Zuber} \mathrm{C}$, Vana $\mathrm{K}$ et al. Therapeutic approaches for prion disorders. Expert 
Rev Anti Infect Ther 2007;5(4):613-630.

58. Vana K, Zuber C, Nikles D, Weiss S. Novel Aspects of Prions, Their Receptor Molecules, and Innovative Approaches for TSE Therapy. Cell Mol Neurobiol 2007;27(1):107-128.

59. Vana K, Zuber C, Pflanz $\mathrm{H}$ et al. LRP/LR as an alternative promising target in therapy of prion diseases, Alzheimer's disease and cancer. Infect Disord Drug Targets 2009;9(1):69-80.

60. Zuber C, Ludewigs H, Weiss S. Therapeutic approaches targeting the prion receptor LRP/LR. Vet Microbiol 2007;123(4):387-393.

61. Miyamoto K, Nakamura N, Aosasa M et al. Inhibition of prion propagation in scrapie-infected mouse neuroblastoma cell lines using mouse monoclonal antibodies against prion protein. Biochem Biophys Res Commun 2005;335(1):197-204.

62. Medical Res Council (GB) US2006280745 (2006).

63. White AR, Enever P, Tayebi $\mathrm{M}$ et al. Monoclonal antibodies inhibit prion replication and delay the development of prion disease. Nature 2003;422(6927):80-83.

\section{•• Describes the first successful passive immunization against prion disease.}

64. Song CH, Furuoka H, Kim CL et al. Effect of intraventricular infusion of anti-prion protein monoclonal antibodies on disease progression in prion-infected mice. J Gen Virol 2008;89(Pt 6):1533-1544.

65. Lefebvre-Roque M, Kremmer E, Gilch S et al. Toxic effects of intracerebral PrP antibody administration during the course of BSE infection in mice. Prion 2007;1(3):198-206.

66. Kagoshima Univ (JP); Search Inst Juridical Foundati (JP); Sugimura Kazuhisa (JP); Nakashima Toshihiro (JP). WO2006046344 (2006).

67. Donofrio G, Heppner FL, Polymenidou M, Musahl C, Aguzzi A. Paracrine inhibition of prion propagation by anti-PrP single-chain Fv miniantibodies. J Virol 2005;79(13):8330-8338.

68. Campana V, Zentilin L, Mirabile I et al. Development of antibody fragments for immunotherapy of prion diseases. Biochem J 2008;

69. Wuertzer CA, Sullivan MA, Qiu X, Federoff HJ. CNS delivery of vectored prion-specific single-chain antibodies delays disease onset. Mol Ther 2008;16(3):481-486.

70. Mandel RJ, Manfredsson FP, Foust KD et al. Recombinant adeno-associated viral vectors as therapeutic agents to treat neurological disorders. Mol Ther 2006;13(3):463-483.

71. Tenenbaum L, Chtarto A, Lehtonen E et al. Recombinant AAV-mediated gene delivery to the central nervous system. J Gene Med 2004;6 Suppl 1:S212-222.

72. Li ZJ, Wang RZ. rAAV vector-mediated gene therapy for experimental ischemic stroke. Neurol India 2008;56(2):116-121.

73. Beck SE, Jones LA, Chesnut K et al. Repeated delivery of adeno-associated virus vectors to the rabbit airway. J Virol 1999;73(11):9446-9455.

74. Halbert CL, Rutledge EA, Allen JM, Russell DW, Miller AD. Repeat transduction in the 
mouse lung by using adeno-associated virus vectors with different serotypes. J Virol 2000;74(3):1524-1532.

75. Lo WD, Qu G, Sferra TJ et al. Adeno-associated virus-mediated gene transfer to the brain: duration and modulation of expression. Hum Gene Ther 1999;10(2):201-213.

76. Mastakov MY, Baer K, Symes CW et al. Immunological aspects of recombinant adeno-associated virus delivery to the mammalian brain. J Virol 2002;76(16):8446-8454.

77. Solforosi L, Criado JR, McGavern DB et al. Cross-linking cellular prion protein triggers neuronal apoptosis in vivo. Science 2004;303(5663):1514-1516.

78. Zuber C, Mitteregger G, Pace $\mathrm{C}$ et al. Anti-LRP/LR antibody W3 hampers peripheral PrPSc propagation in scrapie infected mice. Prion 2007;1(3):207-212.

79. Zuber C, Knackmuss S, Rey C et al. Single chain Fv antibodies directed against the 37 $\mathrm{kDa} / 67 \mathrm{kDa}$ laminin receptor as therapeutic tools in prion diseases. Mol Immunol 2008;45(1):144-151.

80. Weiss Stefan (DE); Little Melvyn (DE); Knackmuss Stefan (DE); Rey Clemence (DE); Roettgen Peter (DE); Buettner Claudia (DE); Reusch Uwe (DE). WO2005035580 (2005).

81. Zuber C, Mitteregger G, Schuhmann N et al. Delivery of single-chain antibodies (scFvs) directed against the $37 / 67 \mathrm{kDa}$ laminin receptor into mice via recombinant adeno-associated viral vectors for prion disease gene therapy. J Gen Virol 2008;89(Pt 8):2055-2061.

82. Meier $\mathrm{P}$, Genoud N, Prinz $\mathrm{M}$ et al. Soluble dimeric prion protein binds $\mathrm{PrP}(\mathrm{Sc})$ in vivo and antagonizes prion disease. Cell 2003;113(1):49-60.

83. Genoud N, Ott D, Braun N et al. Antiprion prophylaxis by gene transfer of a soluble prion antagonist. Am J Pathol 2008;172(5):1287-1296. 
Table 1: Therapeutic chemical agents (see ref. 38 and 39)

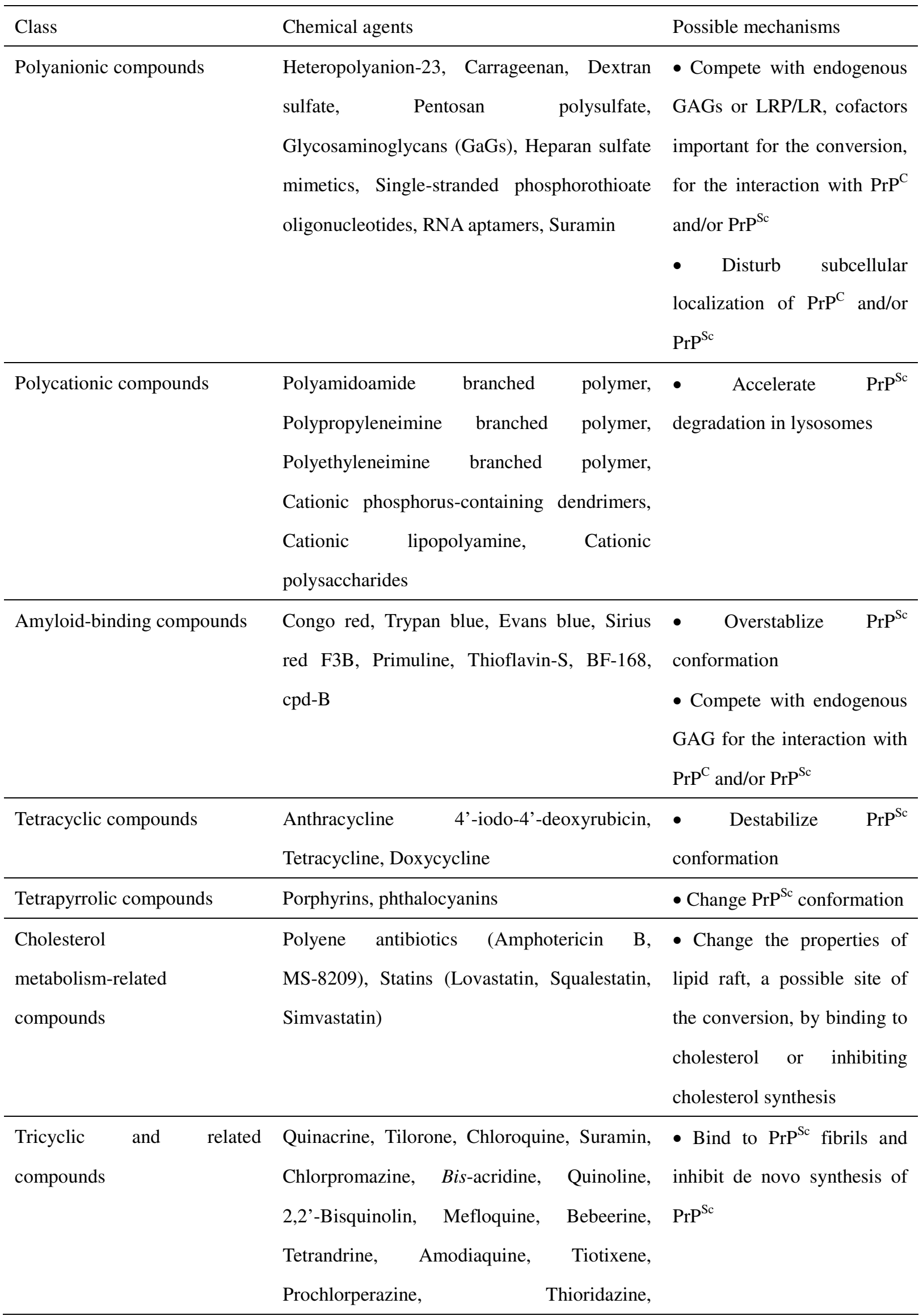




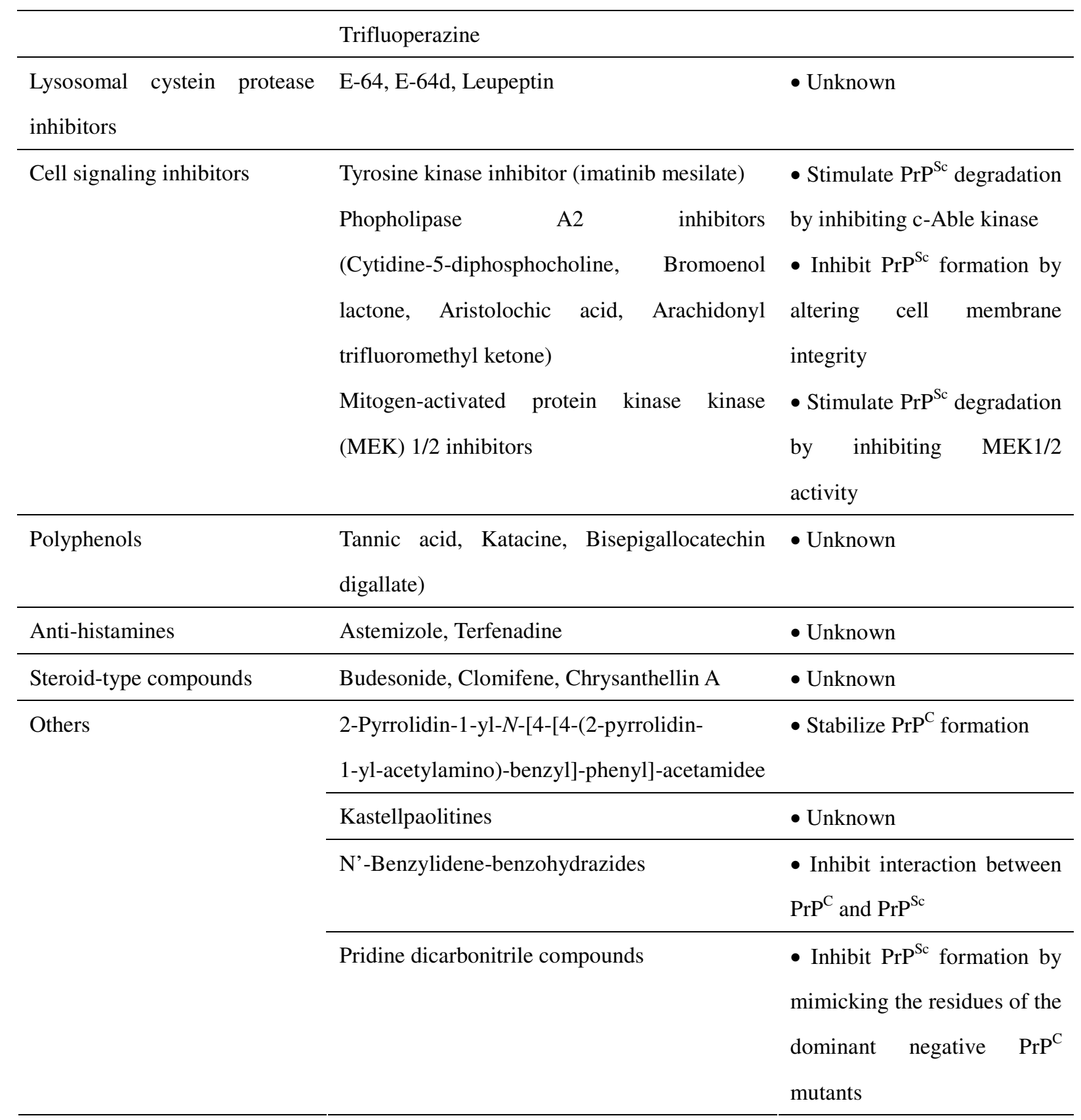


Table 2: No therapeutic effects of intraventricularly administrated-3S9 mAb in Fukuoka-1 prion-infected mice

\begin{tabular}{|c|c|c|c|c|c|c|}
\hline $\begin{array}{l}\text { Treatment } \\
\text { time }\end{array}$ & Antibodies & $\mathrm{N}$ & $\begin{array}{l}\text { Incubation times } \\
\text { (Mean } \pm \mathrm{SD} \text {, days) }\end{array}$ & $\begin{array}{l}P \text { values } \\
\text { (Log-rank } \\
\text { test) }\end{array}$ & $\begin{array}{l}\text { Survival times } \\
\text { (Mean } \pm \text { SD, days) }\end{array}$ & $\begin{array}{l}P \text { values } \\
\text { (Log-rank } \\
\text { test) }\end{array}$ \\
\hline \multirow[t]{2}{*}{8 weeks p.i. } & Control IgG & 6 & $117.8 \pm 9.9$ & 0.158 & $122.5 \pm 6.1$ & 0.273 \\
\hline & $3 \mathrm{~S} 9$ & 5 & $127.0 \pm 9.0$ & & $130.0 \pm 11.7$ & \\
\hline \multirow[t]{2}{*}{13 weeks p.i. } & Control IgG & 5 & $121.2 \pm 2.5$ & 0.851 & $124.0 \pm 3.7$ & 0.942 \\
\hline & $3 \mathrm{~S} 9$ & 6 & $125.0 \pm 4.7$ & & $127.2 \pm 5.8$ & \\
\hline
\end{tabular}

